\title{
PAlarm: a pediatric clinical worsening identification system
}

\author{
Viviana Frigato ${ }^{1 *}$, Liliana Vagliano ${ }^{2}$, Maria Cristina Rossi ${ }^{3}$ \\ From 70th Congress of the Italian Society of Pediatrics, Joint National Meeting SIP, SICuPP, SITIP \\ Palermo, Italy. 11-14 June 2014
}

Rapid Response System (RRS) is by now commonly used and internationally validate to manage in hospital emergency. Both its optimal management and early identification are essential to reduce mortality and neurological sequences of anoxia.

However, in the pediatric Italian population, this system is poorly employ, even if its effectiveness has already been demonstrated.

Therefore, in 2010 at Turin a study [1] was conducted in 5 units of a third level pediatric hospital; the aim was to experiment the only pediatric system completely validate in literature (the Pediatric early Warning Score System). In order to apply this system, it was necessary to adapt it at local reality, analyzing relevant cases (PEWS $\geq 3$ ); all nursing staff underwent an interview to analyze utility and effectiveness of the system.

The obtained results confirm the hypothesis that a PEWS system is suitable for general departments where respiratory pathologies (main cause of death in pediatric age) prevail.

Thanks to this pilot study, the Regina Margherita Children Hospital of Turin has developed the application of this system at the whole hospital, further adjusting it in order to improve the adaptation at local reality, based on preliminary results. The new system has been called PAlarm (Pediatric Alarm), to better connect with METal methodology broadly used for adult patient all over Italian country.

Moreover, specific educational courses has been developed, both for nurses and physicians, in order to correctly apply this system in journal clinical activity.

\footnotetext{
* Correspondence: vivi_fri@hotmail.it

${ }^{1}$ Città della Salute e della Scienza Hospital of Turin - Regina Margherita Children Department, Italy

Full list of author information is available at the end of the article
}

\section{Authors' details}

${ }^{1}$ Città della Salute e della Scienza Hospital of Turin - Regina Margherita Children Department, Italy. ${ }^{2}$ University of Turin - Pediatric Nursing Degree Course Italy. ${ }^{3}$ Città della Salute e della Scienza Hospital of Turin -

Management of In Hospital Emergency Working Group, Italy.

Published: 11 August 2014

\section{Reference}

1. Frigato V, Vagliano L, Bondone C, Grasso G, Urbino A, Bondone C, Rossi MC: Studio sull'applicabilità del Pediatric Early Warning Score System nella pratica infermieristica di un ospedale pediatrico italiano. Children's Nurses - Italian Journal of Pediatric Nursing Science 2013, 5:95-99.

\section{doi:10.1186/1824-7288-40-S1-A51}

Cite this article as: Frigato et al:: PAlarm: a pediatric clinical worsening identification system. Italian Journal of Pediatrics 2014 40(Suppl 1):A51.
Submit your next manuscript to BioMed Central and take full advantage of:

- Convenient online submission

- Thorough peer review

- No space constraints or color figure charges

- Immediate publication on acceptance

- Inclusion in PubMed, CAS, Scopus and Google Scholar

- Research which is freely available for redistribution

Submit your manuscript at www.biomedcentral.com/submit
C Biomed Central 